\title{
THE NATIONAL ROAD FUND AND THE RAILWAY FUND AS A SOURCE OF FINANCING FOR THE DEVELOPMENT OF TRANSPORT INFRASTRUCTURE IN POLAND
}

DATA PRZESŁANIA: 30.11.2018, DATA AKCEPTACJI: 14.01.2019, KODY JEL: R42, E62, H54

\section{Sylwia Kowalska}

University of Szczecin

sylwia.kowalska@wzieu.pl

\begin{abstract}
SUMMARY $\quad$ The article is a review paper whose main objective is to analyze and evaluate the National Road Fund and the Railway Fund as sources of financing infrastructural investments in the transport sector in Poland.

The first part of the article presents the theoretical approach to the financing of transport infrastructure. The essence of investments in both road and rail infrastructure is presented. In addition, selected sources of fundraising for infrastructure investments were discussed on the basis of a literature review. The second part presents and compiles secondary data on financial flows in the National Road Fund and the Railway Fund.

The receipts and expenditures of both Funds were analyzed and their importance in infrastructure financing was determined.

KEYWORDS $\quad$ transport infrastructure, transport financing, infrastructure investments
\end{abstract}

\section{INTRODUCTION}

Transport infrastructure is a fundamental physical and social resource, the presence of which is necessary for proper social and economic functioning and development. It is one of the links in the national economy, whose comprehensive development affects the overall efficiency of the economy. Consequently, economic progress can be reduced through neglects and inaccuracies in the development of transport infrastructure (Grzywacz, 1982). Furthermore, it is noted that there are strong two-way links between the development of transport infrastructure and the improvement of competitiveness and economic and spatial cohesion of the regions. As a result, the development of infrastructure works in favor of equalization of disproportions in the development of regions.

As has been already noted, the basis for economic development is the development of infrastructure. Button (1998) empirically proved a strong link between infrastructure and economic 
growth. Infrastructure supports production, trade development, lower costs, expanding markets, increasing employment, and favors the economic development of the country.

Infrastructure development must take place before needs arise. Negative effects that may arise due to its underdevelopment will affect not only transport, but also other areas of the economy. Disturbances in transport will be manifested primarily through (Wojewódzka-Król, Załoga, 2016):

- increase in time and costs of transport and storage,

- decrease in the quality of transport services,

- structural disadvantages resulting from uneven development of the infrastructure of the various modes of transport,

- emergence of obstacles to the development of transport,

- increase in expenditures on infrastructure development.

The construction and maintenance of infrastructure generate positive externalities not only for the transport sector, but also in other areas of the economy, in the form of stimulating economic growth and development. Well-developed transport infrastructure attracts investors to set up companies and production plants (Audretsch, Heger, Veith, 2015). In a study carried out in Germany, D.B. Audretsch noted that the activity of companies was significantly and positively related to railway infrastructure. He noted that infrastructure may be one of the factors that have been overlooked when researching the activity of enterprises. Improper development of the infrastructure may lead to higher investment costs of enterprises. Moreover, it causes deterioration of the living conditions of the population (Rydzkowski, Wojewódzka-Król, 2009).

The well-being of the population is related to mobility. Mobility, as another aspect, is important for infrastructure development. Infrastructure, in addition to influencing the size of the market and the development of enterprises, is a factor that makes it possible to meet the mobility needs of the society. Moreover, it determines willingness and possibility of movement (Załoga, 2013).

It is also pointed out that the number of cars and trucks is growing dynamically, and consequently, the share of car transport in the transport of goods and passengers is increasing. These are important prerequisites for an increase in the importance of transport infrastructure in Poland. The movement speed is a particularly important postulate put forward by transport users preferences (Kwarciński, 2007).

As a result of socio-economic development, the demand for transport services is increasing and this entails the need to improve existing transport systems and increase transport production volumes, which can be achieved through infrastructure investments. The construction of a new transport network and the modernization of the existing one entails the need to raise funds.

Therefore, it is so important to obtain and target financial resources in order to implement infrastructural investments both in Poland and in other EU countries.

\section{FINANCING OF TRANSPORT INFRASTRUCTURE IN POLAND}

According to the basis of transport economics, one of the inherent features of transport infrastructure is its high wealth and capital intensity (Burnewicz, Grzywacz, 1989). In order to maintain and modernize it, it is necessary to incur high capital expenditure (capital intensity) on infrastructure. Moreover, it has a large share in the total value of national assets (capital intensity), and, as a result, 
its other characteristic - technical indivisibility. If this condition is not met, it may result in infrastructure decapitalization and technical degradation. The consequence may be a deterioration of its quality and usability (Dyr, Kozubek, 2011).

Infrastructure investments require significant capital expenditure, which is non-refundable or has a long payback period. As infrastructure is often monopolistic, the provision of funds by a single supplier can be optimal from an efficiency point of view (Audretsch, Heer, Veith, 2015).

It is characteristic of infrastructure that it is financed from public funds. Due to the need to engage high financial outlays in the long term, private capital investments are used to a lesser extent. In addition, infrastructure and its components serve the general economic and social good by virtue of its universal nature. The country, as the main entity, has the ability to engage large capital that does not bring average profitability (Grzywacz, 1982). However, along with the growing investment needs and the resulting shortages of public funds, there is a growing interest in raising private capital.

In the current economic practice, due to underinvestment in infrastructure and the emergence of the so-called "infrastructure gap", the emphasis is placed on the more widespread use of the model of public-private partnership, which aims at running, financing and exploitation of infrastructure investments. The authorities of European countries, including Poland, place increasing emphasis on the use of the PPP model. This model consists in including the private sector into the public sector (Brzozowska, 2010).

Khmel and Zhao (2016) note that the growing demand for infrastructure and, on the other hand, financial and budgetary constraints are constantly increasing this gap. In addition, capital raised from various sources should be integrated with sustainable instruments at the right time in the project life cycle.

On the basis of the bibliometric analysis, Kumari and Sharma (2017) show that the PPP model is the preferred form of infrastructure investments. Infrastructure, as the core of all economic and social activities, helps to reduce barriers to development, such as unemployment, poverty, regional inequality or low productivity. Despite the fact that there are several sources of financing infrastructure investments, the PPP model is indicated as the preferred source of expenditure on the construction and maintenance of infrastructure.

In Poland, as part of government road projects which are covered by PPP financing, 3 sections of highways have been created, among others:

- A1 highway (152 km) - section of Rusocin - Nowe Marzy, managed by a special purpose entity AmberOne,

- A2 highway $(255 \mathrm{~km})$ - section of Świecko - Nowy Tomyśl - Konin, managed by Autostrada Wielkopolska SA and Autostrada Wielkopolska II SA,

- A4 highway $(61 \mathrm{~km})$ - section of Kraków - Katowice, managed by Stalexport Autostrada Małopolska.

Another important source of financing for infrastructure projects is European funds. Poland's accession to the European Union has created new conditions for the functioning and development of the country's transport system. This is connected, among other things, with the creation of new sources of funds for the implementation of infrastructural investments. 
Cohesion policy is the European Union's main instrument for achieving convergence and increasing the competitiveness of countries and regions, as well as of the entire EU territory. Financial support can be implemented using (Załoga, 2013):

- national budgets of the Member States,

- general budget of the EU,

- pre-accession programs,

- structural funds (ERDF, Cohesion Fund),

- dedicated budgets: TEN-T Fund for the period 2014-2020 - Connecting Europe Facility Fund (CEF),

- Marco Polo program,

- loans from the European Investment Bank,

- capital of private investors,

- transport users' charges.

European funds can also support transport infrastructure financing models within the PPP framework. On the example of Spain, it is noted that the European Investment Bank plays the largest role. On the basis of the studies carried out, a positive link between European financial support and the economic viability of PPP has been identified. Projects supported financially by EU funds showed higher profitability (Garrido et al., 2017).

The high financial demand for infrastructure projects and the creation of an infrastructure gap related to underfunding is associated with a greater emphasis on charging users with infrastructure costs under the "user pays" principle. Currently, both in Poland and other European countries, in addition to public funds allocated for the construction and modernization of infrastructure, charges are levied for the use of the transport network.

Road user charges play an important role in financing transport infrastructure in this respect. They are collected in the form of vignettes or tolls, and the basic legal act implementing them was Directive 62/1999 of 17 June 1999. According to the Directive, a Member State could introduce the obligation to pay road tolls for vehicles on roads of a higher standard, whose weight exceeded 12 tonnes (Wojewódzka-Król, Rolbiecki, 2018).

For Poland, modernization and development of infrastructure have long been one of the main priorities of the country policy. Access to and quality of infrastructure is a determinant of the attractiveness of a given area for business entities. It is a condition for the development of the economy and its competitiveness, as well as determines the standard of living of the inhabitants. Therefore, infrastructure financing is still the most important task and at the same time the most important function of road tolls. These tolls are an important source of financial income for the country budget and for road managers. The costs of construction and maintenance of highways are transferred to the user and a stable source of funding for the maintenance of the road network is created.

Revenues from electronic and stationary toll collection feed into the National Road Fund, which supports the financing of road investments in Poland. 


\section{IMPORTANCE OF THE NATIONAL ROAD FUND AND RAILWAY FUND FOR DEVELOPMENT}

Financing of infrastructure through loans, EU funds and tolls obtained from road users takes place mainly through the National Road Fund and the Railway Fund.

The National Road Fund (Krajowy Fundusz Drogowy, KFD) was established pursuant to the Act of 27 October 1994 on toll highways and the National Road Fund (Dz.U. [Journal of Laws] of 2004, No. 256, item 2571). The company commenced operations on 1 January 2004 and the Governmental Program for the Construction of Roads and Highways in Poland is the basis for the operation of the Fund. The obligation to finance investments was transferred from the country budget to KFD. A flexible model of road infrastructure financing has been created. It assumed concentration of all funds allocated for the implementation of road investments, both those obtained from national sources and from the European Union.

The main objective of the Fund is to concentrate capital to be used for the future creation of road infrastructure or its reconstruction. However, it finances only national roads, not those within the territory and under the jurisdiction of district authorities. In addition, these funds are also used for (Krzak, 2012):

- payment to the companies for the performance of possible works resulting from previously signed agreements,

- creation of databases on already created structures and road networks,

- repayment of debts contracted for the Fund,

- creation and maintenance of a toll collection system,

- covering the costs of creating and operating engineering structures and crossings in water transport.

A detailed list of receipts and expenditures of the National Road Fund budget in the years 2008-2015 is presented in Table 1.

Table 1. KFD financial flows in 2008-2015 (in PLN million)

\begin{tabular}{|c|c|c|c|c|c|c|c|c|}
\hline Specification & 2008 & 2009 & 2010 & 2011 & 2012 & 2013 & 2014 & 2015 \\
\hline Receipts to the Fund: & 3054.5 & 14494.5 & 19530.0 & 26083.0 & 25845.4 & 13179.0 & 17756.5 & 11427.8 \\
\hline Receipts from the fuel fee & 1469.3 & 1414.3 & 2935.3 & 3274.7 & 3538.1 & 3587.4 & 3863.9 & 3972.4 \\
\hline Receipts from EU funds & 36.0 & 85.8 & 4944.3 & 10437.8 & 14282.2 & 5297.6 & 5187.1 & 2988.0 \\
\hline $\begin{array}{l}\text { Receipts from incurred credit } \\
\text { liabilities }\end{array}$ & 373.3 & 2238.0 & 4166.9 & 3190.7 & 2494.5 & 2617.6 & 5314.4 & 2170.7 \\
\hline Receipts from the issue of bonds & 350.0 & 7758.7 & 6326.3 & 8026.4 & 3916.7 & 0.0 & 1289.1 & 0.0 \\
\hline Transitional financing & 0.0 & 2000.0 & 113.8 & 0.0 & 0.0 & - & - & - \\
\hline $\begin{array}{l}\text { Receipts under the concession } \\
\text { system (and toll collection after } \\
\text { the introduction of an electronic } \\
\text { toll collection system) }\end{array}$ & 767.0 & 922.0 & 901.9 & 1031.6 & 1305.6 & 1426.8 & 1765.1 & 1873.6 \\
\hline Other receipts & 58.9 & 997.7 & 141.4 & 121.7 & 308.3 & 249.6 & 337 & 423.1 \\
\hline Expenses of the Fund: & 3019.5 & 13440.8 & 20066.2 & 26246.1 & 23286.3 & 14269.9 & 17977.5 & 12743.9 \\
\hline $\begin{array}{l}\text { Expenses for investment tasks. } \\
\text { the process of preparation. } \\
\text { renewal and maintenance of the } \\
\text { road network }\end{array}$ & 1927.5 & 10040.6 & 16785.2 & 23029.7 & 18598.2 & 10000.7 & 6726.5 & 8658.8 \\
\hline
\end{tabular}




\begin{tabular}{|l|c|c|c|c|c|c|c|c|}
\hline \multicolumn{1}{|c|}{ Specification } & 2008 & 2009 & 2010 & 2011 & 2012 & 2013 & 2014 & 2015 \\
\hline $\begin{array}{l}\text { Expenses for servicing loans and } \\
\text { bonds }\end{array}$ & 282.4 & 500.5 & 2073.6 & 1911.6 & 2718.3 & 2400.1 & 9484.3 & 2335.9 \\
\hline $\begin{array}{l}\text { Expenses for transitional } \\
\text { financing }\end{array}$ & 0.0 & 2009.4 & 113.8 & 0.0 & 0.0 & 0.0 & 0.0 & 0.0 \\
\hline $\begin{array}{l}\text { Expenses for BGK commission } \\
\text { remuneration }\end{array}$ & 4.5 & 4.4 & 7.4 & 8.2 & 8.5 & 6.0 & 8.2 & 8.6 \\
\hline $\begin{array}{l}\text { Expenses under the "concession" } \\
\text { system }\end{array}$ & 760.6 & 843.9 & 952.4 & 1265.0 & 1864.8 & 1702.4 & 1690.3 & 1663.9 \\
\hline $\begin{array}{l}\text { Expenses for the liquidation of } \\
\text { flood effects }\end{array}$ & 0.0 & 0.0 & 103.0 & 0.0 & 0.0 & 0.0 & 0.0 & 0.0 \\
\hline Other expenses & 44.5 & 42.0 & 30.8 & 31.6 & 96.5 & 160.7 & 68.2 & 76.7 \\
\hline
\end{tabular}

Source: Own study based on: Activity reports of Bank Gospodarstwa Krajowego for the years 2008-2015.

Due to the need to develop different methods of distribution of influence in selected years, the following categories have been included by the author into the category "Other receipts": "Budgetary resources", "Other receipts", "Receipts from the amounts recovered by GDDKiA on the basis of the Act on repayment of selected unsatisfied claims of entrepreneurs arising from awarded public procurement orders" and "Different receipts", which in the BGK report constitute separate categories. In addition, in the category "Other expenses" the author included: "Payments to subcontractors on the basis of the Act on repayment of selected unsatisfied claims of entrepreneurs arising from awarded public procurement orders", "Advisory services", "Collection of data on public roads", and "Other expenses".

An important period for KFD was 2009 when its importance and role in financing road infrastructure projects increased. A significant increase in receipts can be observed between 2008 and 2011. In 2008, revenues to the budget of the Fund amounted to just over PLN 3 billion, and already in 2011 increased to over PLN 26 billion. A significant drop in revenues took place in 2013 and this was related mainly to the reduction of European subsidies. In 2014, KFD revenues increased significantly due to loans taken out and the issue of bonds.

On 1 January 1998, a road tax was introduced, which was included in the excise duty on fuels. However, it was not until January 2006 that its revenues were designed for the maintenance, modernization and development of the national, provincial and district infrastructure.

Regular and each year increasing, receipts from fuel surcharge are paid to the Fund. This source accounted for approximately one-third of all receipts in 2015. Also important from the point of view of regularity is the road toll, which increased by $208 \%$ in 2015 compared to 2010.

A similar trend may also be observed with regard to expenditure. In 2008, the National Road Fund allocated almost PLN 2 billion for road tasks and by 2011 they had increased twelvefold. The largest share of KFD expenditures is expenditures on investment tasks, the process of preparation, renovation and maintenance of the road network. Since 2011, KFD expenditures (except for 2014, when the cost of servicing loans and bonds was record high) have been decreasing.

As shown in Figure 1, KFD significantly supports the implementation of road investments. 


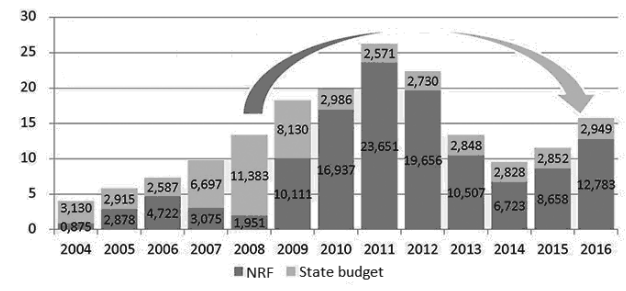

Figure 1: Expenditures on road tasks in the years 2004-2016 in PLN billion

Source: https://www.nik.gov.pl/aktualnosci/inwestycje-drogowe-zabezpieczenie-interesu-skarbu-panstwa-i-podwykonawcow. html (access: 4.01.2018).

Road tasks outside the National Road Fund are carried out with the support of the country budget. In the years 2004-2016, nearly PLN 55 billion was allocated from the country budget for road investments. Of the PLN 177 billion which were allocated to road investments at that time, the funds from the budget amount to approx. $30 \%$ of all incurred expenses. The remaining part of expenditures was covered from the funds of the National Road Fund.

This shows that KFD is an important source of investment and infrastructure maintenance, which has covered a significant part of expenditure since 2010. It has the potential to reduce budget expenditure on investment and thus close the infrastructure gap.

In addition to the National Road Fund, the Railway Fund (Fundusz Kolejowy, FK) has been commenced to implement investments in rail transport in Poland.

The Railway Fund was established by virtue of the Act of 16 December 2005 on the Railway Fund and has been operating within the structures of Bank Gospodarstwa Krajowego since 2006.

The aim of the Fund is primarily funding of (www.bgk.pl):

- tasks consisting in the preparation and implementation of construction and reconstruction of railway lines,

- tasks related to the renovation and maintenance of railway lines and the elimination of unnecessary railway lines,

- current expenditures of PKP Polskie Linie Kolejowe SA related to the activity consisting in the management of railway infrastructure,

- in 2009-2020, tasks of voivodship self-governments in the scope of purchase, modernization and repair of railway vehicles intended for passenger transport, performed under a public service contract (in 2009, PLN 200 million, in 2010-2015, PLN 100 million per year, in 2016-2020, PLN 110 million per year),

- purchase and modernization by PKP Polskie Linie Kolejowe SA of railway vehicles intended for diagnostics, maintenance, repair or construction of railway infrastructure and for carrying out rescue operations.

As shown in Table 2, the main source of FK's revenue is the fuel surcharge paid on fuels placed on the domestic market. It is $20 \%$ of the total payment ( $80 \%$ goes to the National Road Fund). This is an example of cross-subsidization. In terms of financial flows, this means that revenue from one mode of transport is allocated for expenditure in other modes; this situation primarily takes place in rail transport (Bąk, 2012). This is the case when the Railway Fund is supplied with funds obtained from fees paid by importers and fuel producers. 
Table 2. FK financial flows in 2011-2016 (in PLN million)

\begin{tabular}{|l|c|c|c|c|c|c|}
\hline \multicolumn{1}{|c|}{ Specification } & 2011 & 2012 & 2013 & 2014 & 2015 & 2016 \\
\hline Receipts to the Fund: & $\mathbf{1 0 6 1 . 7}$ & $\mathbf{1 0 2 1 . 8}$ & $\mathbf{1 0 3 9 . 1}$ & $\mathbf{1 1 0 2 . 6}$ & $\mathbf{1 6 3 7 . 8}$ & $\mathbf{1 7 4 8 . 2}$ \\
\hline Receipts from the fuel fee & 943.7 & 1009.5 & 1021.9 & 1091.0 & 1618.1 & 1718.3 \\
\hline Other receipts & 118.0 & 12.3 & 17.2 & 11.7 & 19.7 & 29.9 \\
\hline Expenses of the Fund: & $\mathbf{1 2 1 1 . 6}$ & $\mathbf{8 0 6 . 1}$ & $\mathbf{1 2 4 8 . 7}$ & $\mathbf{1 0 0 3 . 3}$ & $\mathbf{1 3 0 9 . 2}$ & $\mathbf{1 4 5 3 . 0}$ \\
\hline For investments in railway infrastructure & 367.4 & 149.9 & 266.8 & 187.1 & 369.8 & 1036.1 \\
\hline $\begin{array}{l}\text { For renovations and maintenance of railway } \\
\text { infrastructure }\end{array}$ & 91.9 & 47.0 & 329.8 & 67.0 & 224.8 & 0.0 \\
\hline $\begin{array}{l}\text { For the purchase. modernization and } \\
\text { repair of railway vehicles - voivodship self- } \\
\text { governments }\end{array}$ & 141.0 & 94.1 & 86.6 & 134.2 & 115.7 & 90.2 \\
\hline $\begin{array}{l}\text { For the purchase by SP of stocks and shares } \\
\text { from PKP SA }\end{array}$ & 500.0 & 350.0 & 500.0 & 0.0 & - & - \\
\hline $\begin{array}{l}\text { For expenditures of PKP PLK SA on } \\
\text { infrastructure management }\end{array}$ & 0.0 & 14.5 & 65.0 & 614.3 & 598.1 & 325.8 \\
\hline Other expenses & 111.3 & 150.6 & 0.6 & 0.6 & 0.7 & 0.9 \\
\hline
\end{tabular}

Source: Own study based on: Activity reports of Bank Gospodarstwa Krajowego for the years 2011-2016.

The volume of income has been growing since 2012. A particularly large increase may be seen in 2015. This is due to the increase in traffic and the fuel surcharge rate. In connection with the need to increase the financial capacity to carry out infrastructural investments, under three legal acts (the Act of 6 December 2008 on Excise Duty, the Act of 27 October 1994 on Toll Highways and the National Road Fund and the Act of 16 December 2005 on the Railway Fund) the amount of fuel fee which is spent on infrastructural investments has been increased. At the same time, the excise duty was reduced by the same amount, so the price of fuels did not change significantly.

As a result, budget receipts in the period 2015-2019 will decrease, while receipts of the Fund will increase. In 2015, receipts to FK increased by over PLN 500 million as a result of the increase in fuel fee. In 2016, compared to the previous year, the increase was more than 110 million. It is predicted that by 2019 the amount of the fuel fee feeding the Fund will be similar to the 2016 figure.

The resources of the Fund are allocated to infrastructural investments related to the construction, maintenance and modernization of railway infrastructure. Compared to KFD, the share of the Railway Fund has a much smaller share in the financing of railway infrastructure in comparison to expenditure from the country budget.

\section{CONCLUSIONS}

Transport infrastructure is a very important component of national wealth. Constantly increasing transport needs in both passenger and freight transport contribute to increasing the role of infrastructure investments. Modernization of the existing infrastructure is aimed at improving its quality, while its development is intended to increase its accessibility. These actions are related to the need to engage financial resources. 
The National Road Fund and the Railway Fund are important sources of financing. As can be seen from the example of KFD, it provides a significant part of these funds, thus relieving the country budget and making itself partly independent from EU funds.

Fuel and road tolls represent significant revenue for KFD. In accordance with the "user pays" principle, they ensure significant receipts (approx. 50\% of all receipts). Considering the fact that in the same year the KFD covered more than $75 \%$ of road investments (the remaining $25 \%$ was covered by the country budget), this is a premise for more effective use of the KFD as a source of road investments.

The main source of income of the Railway Fund is the fuel fee. In accordance with the assumptions of the common transport policy of the European Union Member States, the use of environmentally harmful modes of transport should be reduced. In order to achieve this, the quality and accessibility of the infrastructure of alternative modes of transport should be improved. The Railway Fund contributes to the achievement of these objectives, which acts as an incentive to increase its use in line with the objectives of the common transport policy.

\section{REFERENCES}

Audretsch, D.B., Heger, D., Veith, T. (2015). Infrastructure and entrepreneurship. Small Business Economics, 44 (2), $219-230$. DOI: $10.1007 / \mathrm{s} 11187-014-9600-6$.

Bąk, M. (2012). Dylematy wokół zapewniania środków na finansowanie infrastruktury transportowej. II Europejski Kongres Finansowy. Retrieved from: https://www.efcongress.com/sites/default/files/m.bak_dylematywokolzapewnianiasrodkownafinansowanie.pdf.

Brzozowska, K. (2010). Innowacyjność partnerstwa publiczno-prywatnego w rozwoju infrastruktury transportu w Europie. EkonomiczneProblemy Ustug, 59, 37-50.

Burnewicz, J., Grzywacz, W. (1989). Ekonomika transportu. Gdańsk: Wydawnictwo Komunikacji i Łączności.

Button, K. (1998). Infrastructure investment, endogenous growth and economic convergence. The Annals of Region Science, 32 (1), 145-162.

Dyr, T., Kozubek, P. (2011). Ocena inwestycji infrastrukturalnych. Radom: Instytut Naukowo-Wydawniczy Spatium.

Garrido, L., Gomez, J., de los Angeles Baeza, M., Vassallo, J.M. (2017). Is EU financial support enhancing the economic performance of PPP. Transport Policy, 56, 19-28.

Grzywacz, W. (1982). Infrastruktura transportu. Warszawa: Wydawnictwo Komunikacji i Łączności.

Khmel, V., Zhao, S. (2016). Arrangement of financing for highway infrastructure projects under the conditions of PublicPrivate Partnership. IATSS Research, 39 (2), 138-145.

Korolewska, M. (2012). Wydatki publiczne na infrastrukturę transportu lądowego w Polsce. Studia BAS, 32 (4), 79-124.

Krzak, J. (2012). Systemy opłat elektronicznych w drogowym transporcie towarowym Unii Europejskiej. Studia BAS, 32 (4), 125-144.

Kumari, A., Sharma, A.K. (2017). Infrastructure financing and developement: A bibliometric review. International Journal of Critical Infrastructure Protection, 16, 49-65.

Kwarciński, T. (2007). Kierunki rozwoju infrastruktury drogowej w Polsce. In: Z badań nad transportem i polityka gospodarcza. Ed.: S. Flejterski, E. Załoga. Szczecin: Wydawnictwo Naukowe Uniwersytetu Szczecińskiego

Rydzkowski, W., Wojewódzka-Król, K. (2009). Transport. Gdańsk: PWN.

Wojewódzka-Król, K., Rolbiecki, R. (2018). Infrastruktura transportu. Warszawa: PWN.

Wojewódzka-Król, K., Załoga, E. (2016). Transport. Nowe wyzwania. Warszawa: PWN.

Załoga, E. (2013). Trendy w transporcie lądowym Unii Europejskiej. Szczecin: Wydawnictwo Naukowe Uniwersytetu Szczecińskiego. 


\section{Legal acts:}

Dyrektywa 1999/62/WE Parlamentu Europejskiego i Rady z dnia 17 czerwca 1999 roku w sprawie pobierania opłat za użytkowanie niektórych typów infrastruktury przez pojazdy ciężarowe

Ustawa z dnia 6 grudnia 2008 roku o podatku akcyzowym.

Ustawa z dnia 27 października 1994 roku o autostradach płatnych oraz o Krajowym Funduszu Drogowym.

Ustawa z dnia 16 grudnia 2005 roku o Funduszu Kolejowym.

Krajowy Fundusz Drogowy oraz Fundusz Kolejowy jako źródło finansowania rozwoju infrastruktury transportu w Polsce

\section{KRAJOWY FUNDUSZ DROGOWY ORAZ FUNDUSZ KOLEJOWY JAKO ŹRÓDŁO FINANSOWANIA ROZWOJU INFRASTRUKTURY TRANSPORTU W POLSCE}

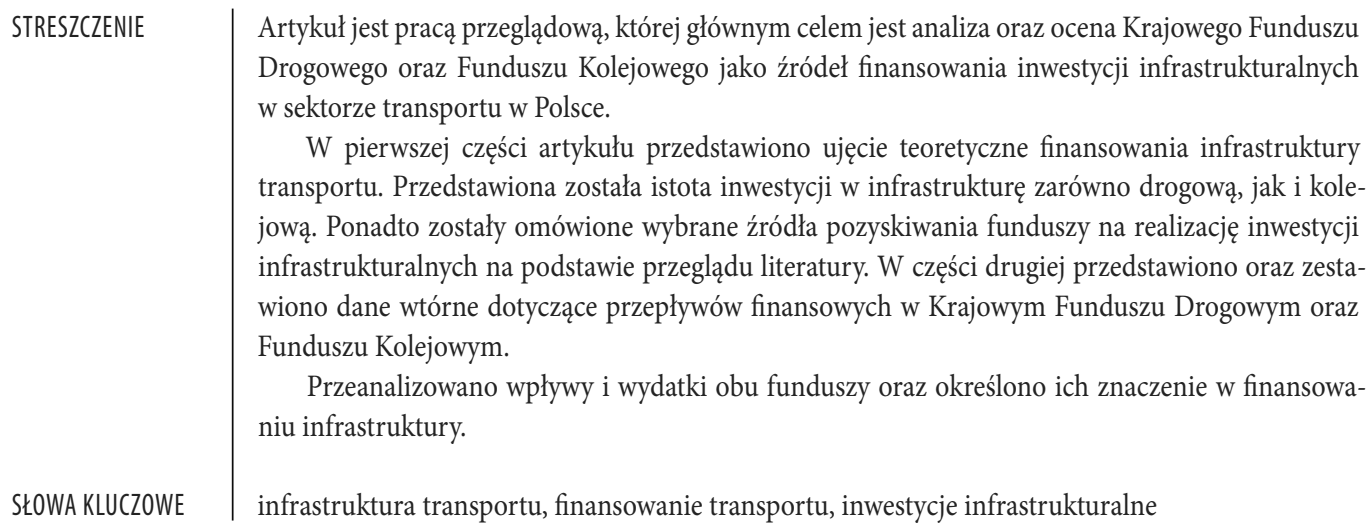

